\title{
Laboratoryjne obrazowanie wielkości wgniatania ziaren podsadzki w ścianę szczeliny
}

\section{Laboratory imaging of the size of the propagation of proppant grains into the fracture wall}

\author{
Mateusz Masłowski \\ Instytut Nafty i Gazu - Państwowy Instytut Badawczy
}

\begin{abstract}
STRESZCZENIE: Autor przedstawił laboratoryjną symulację oraz obrazowanie wielkości zjawiska wgniatania ziaren materiału podsadzkowego w ścianę szczeliny (ang. embedment). Zjawisko embedment występuje po wykonanym zabiegu hydraulicznego szczelinowania złoża (po zaciśnięciu się górotworu). W artykule przedstawiono tematykę związaną z uszkodzeniem powierzchni szczeliny spowodowanym wgniataniem ziaren materiału podsadzkowego w jej ścianę. Ma ono negatywny wpływ na przepływ węglowodorów ze skały do podsadzonej podsadzką szczeliny oraz na utrzymanie jej rozwartości po zaciśnięciu się górotworu. Opracowaną metodykę obrazowania wielkości zjawiska wgniatania podsadzki zweryfikowano testami laboratoryjnymi. Badania wykonano dla lekkiej podsadzki ceramicznej 30/50 o rozmiarze ziaren rzędu $0,600-0,300 \mathrm{~mm}$ oraz płynu szczelinującego na bazie naturalnego polimeru liniowego o koncentracji $3,6 \mathrm{~kg} / \mathrm{m}^{3}$. Technologia ta stosowana jest często do szczelinowania złóż niekonwencjonalnych typu łupkowego shale gas oraz piaskowców typu tight gas. Badania wykonano dla wstępnie nasyconej płynem szczelinującym skały pochodzącej ze złoża niekonwencjonalnego, charakteryzującej się podwyższoną zawartością minerałów ilasto-mułowcowych. Podsadzka była umieszczona pomiędzy dwoma kształtkami skalnymi, a jej koncentracja powierzchniowa wynosiła $2,44 \mathrm{~kg} / \mathrm{m}^{2}$. Do badań przyjęto temperaturę $70^{\circ} \mathrm{C}$ oraz naprężenie ściskające $48,3 \mathrm{MPa}$. Czas zadanego oddziaływania naprężenia ściskającego na warstwę podsadzki wynosił 6 godz. Wyznaczono całkowitą średnią głębokość wgnieceń podsadzki w ściany szczeliny, która wynosiła 0,1028 mm, a całkowita średnia szerokość wgnieceń ziaren podsadzki w ściany szczeliny wynosiła 0,3056 mm. Całkowite procentowe uszkodzenie powierzchni ściany szczeliny przez ziarna podsadzki było rzędu 38,7\%. Wynik laboratoryjnego obrazowania wielkości wgniatania ziaren materiału podsadzkowego w ścianę szczeliny (zjawisko embedment) może stanowić wstępną ocenę efektywności podsadzenia szczeliny w zabiegach hydraulicznego szczelinowania na etapie ich projektowania.
\end{abstract}

Słowa kluczowe: wgniatanie podsadzki, hydrauliczne szczelinowanie, podsadzka, płyn szczelinujący, złoża niekonwencjonalne.

ABSTRACT: The author presented a laboratory simulation and imaging of the size of the phenomenon of embedding the grains of proppant into the fracture wall (embedment). The appearance of the embedment occurs after the hydraulic fracturing of the hydrocarbons reservoir (after closing of the rock mass). The article presents the subject matter related to the damage of the fracture wall surface caused by the embedding of grains of backfilling material into the fracture wall. It has a negative effect on the flow of hydrocarbons from the rock to the proppant-packed fracture and to maintain the width openness after the closing of the rock mass. The developed methodology for imaging the size of the embedment phenomenon was verified by laboratory tests. The tests were performed for a lightweight ceramic $30 / 50$ with a grain size of $0.600-0.300 \mathrm{~mm}$ and a fracturing fluid linear polymer 30 \# (guar) with a concentration of $3.6 \mathrm{~kg} / \mathrm{m}^{3}$. This technology is often used for fracturing unconventional shale gas deposits and tight gas sandstones. The tests were conducted for initially soaked rock coming from an unconventional deposit with fracturing fluid, characterized by an increased content of clay-mud minerals. The proppant was placed between two cylindrical rock cores. The surface concentration of the proppant was $2.44 \mathrm{~kg} / \mathrm{m}^{2}$. The time of exposure of proppant grains to compressive stress of a value $48.3 \mathrm{MPa}$ for 6 hours at $70^{\circ} \mathrm{C}$. The total average depth of embedding the proppant grains into the fracture wall was $0.1028 \mathrm{~mm}$. The total average width of embedding the proppant grain into the fracture wall was $0.3056 \mathrm{~mm}$. The total percentage damage of the fracture wall surface by the proppant grains was $38.7 \%$. The result of the laboratory imaging of embedding the proppant grains into the fracture wall (phenomenal embedment) may be one of the preliminary assessments of the effectiveness of hydraulic fracturing at the design stage.

Key words: embedment, hydraulic fracturing, proppant, fracturing fluid, unconventional reservoirs.

Autor do korespondencji: M. Masłowski, e-mail: mateusz.maslowski@inig.pl

Artykuł nadesłano do Redakcji: 21.03.2019 r. Zatwierdzono do druku: 11.07.2019 r. 


\section{Wstęp}

Złoża niekonwencjonalne typu łupkowego, z których od kilkunastu lat na świecie pozyskuje się tzw. gaz z łupków (ang. shale gas), charakteryzują się bardzo niską porowatością oraz przepuszczalnością (w niektórych przypadkach nawet poniżej $0,001 \mathrm{mD}$ ). W sytuacji podwyższonej zawartości minerałów ilastych, charakteryzują się one niskimi modułami Younga i wysokimi współczynnikami Poissona, co przekłada się na niskie wartości wskaźnika kruchości brittleness, tj. wysoką plastyczność (Moska et al., 2018; Kasza, 2019). Taka struktura szkieletu skalnego jest przyczyną niskiej przepuszczalności gazu w formacjach tego rodzaju. Rozwiązaniem tego problemu jest wykonanie zabiegu hydraulicznego szczelinowania, aby skutecznie wytworzyć w nich system szczelin i mikropęknięć umożliwiających uwolnienie się zaadsorbowanego gazu i jego przepływ przez indukowane pory do odwiertu (Reinicke et al., 2006; Kasza, 2011; Morales, 2012; Czupski et al., 2013; Kasza, 2019). Wytworzone szczeliny charakteryzują się małą szerokością (rozwartością) oraz dużym zasięgiem w złoże. Geometria wytworzonych szczelin jest bardzo złożona i zależna od obszarów zdolnych do pękania.

\section{Zjawisko wgniatania ziaren podsadzki w ścianę szczeliny (embedment)}

Zjawisko embedment ma miejsce po wykonanym zabiegu hydraulicznego szczelinowania i zaciśnięciu się górotworu. Wpływa ono na uszkodzenie powierzchni ściany szczeliny, związane z kruszeniem się ziaren skały złożowej. Powoduje to zagęszczanie się ich okruchów w strefie ściany szczeliny (Reinicke et al., 2006; 2010). Tym samym ogranicza powierzchnię kontaktu złoża z wytworzoną szczeliną, po wykonanym zabiegu hydraulicznego szczelinowania (rys. 1).

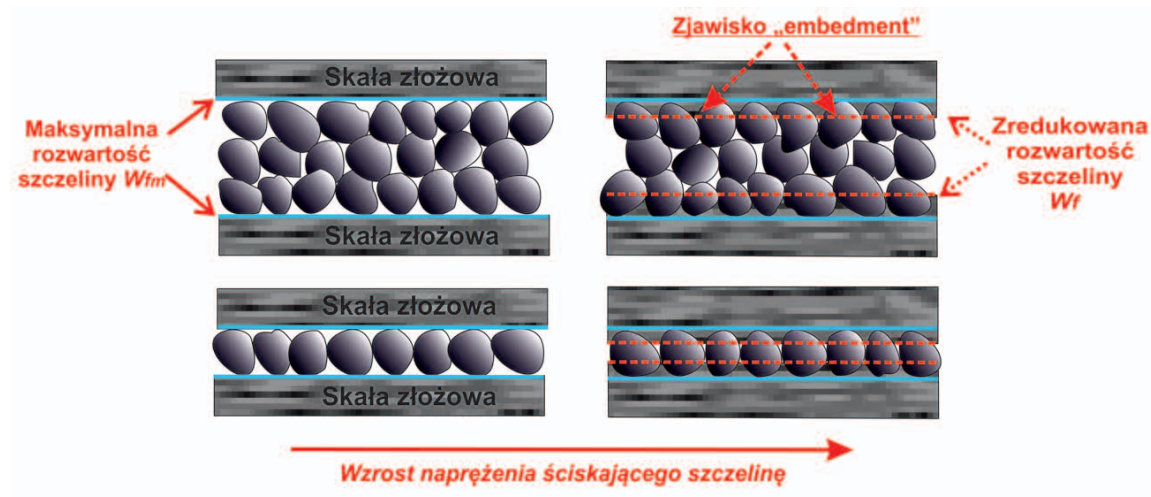

Rys. 1. Zjawisko wgniatania ziaren podsadzki w ścianę wytworzonej szczeliny po zaciśnięciu się górotworu

Fig. 1. The effect of embedment phenomenon on the fracture pack width, after closed of the rock mass
Literatura podaje, że na wielkość zjawiska embedment wpływa między innymi: rodzaj skały złożowej (skład mineralogiczny), technologia zabiegu szczelinowania (rodzaj płynów szczelinujących), rodzaj podsadzki, wielkość naprężeń ściskających i temperatura.

Od wielu lat podejmuje się szereg badań laboratoryjnych oraz prób matematycznego obrazowania (modelowania) zjawiska wgniatania ziaren podsadzki w skałę złożową (ścianę wytworzonej szczeliny) (Legarth et al., 2005; Reinicke et al., 2006; Alramahi et al., 2012; Guo et al., 2012; Morales, 2012; Masłowski, 2015; Masłowski i Biały, 2016; Masłowski et al., 2018a, 2018b). Polegają one na określeniu wpływu zjawiska embedment na efektywne podsadzenie wytworzonej w skale złożowej szczeliny. Wraz ze wzrostem możliwości sprzętowych oraz oprogramowania komputerowego są one unowocześniane, pozwalając tym samym na lepsze odwzorowanie zjawiska embedment.

\section{Metodyka obrazowania wpływu płynu szczelinującego na wielkość zjawiska embedment}

Prawidłowe wykonanie laboratoryjnego obrazowania wielkości zjawiska embedment wymaga między innymi: zebrania informacji odnośnie warunków złożowych, technologii wykonania zabiegu hydraulicznego szczelinowania złoża, rodzaju skały złożowej, przygotowania próbek skały, wyznaczenia pierwotnej chropowatości ściany szczeliny, laboratoryjnego zasymulowania zjawiska embedment oraz właściwej analizy uzyskanych wyników (Gidley et al., 1989; Masłowski, 2015; Masłowski et al., 2016; 2018a, 2018b).

Charakterystyka warunków złożowych wymaga uzyskania informacji odnośnie: głębokości, temperatury, naprężeń ściskających w złożu (ciśnienie zaciśnięcia się górotworu) oraz szybkości zaciskania się górotworu po zakończeniu zabiegu szczelinowania (Gidley et al., 1989; Masłowski, 2015; Masłowski i Biały, 2016; Masłowski et al., 2018a, 2018b). Niezbędne jest również zgromadzenie danych odnośnie rodzaju płynu szczelinującego i podsadzki, użytych w zabiegu szczelinowania. Cylindryczne rdzenie skalne powinny być wycięte ze skały złożowej odpowiadającej głębokości wykonania zabiegu szczelinowania, o średnicy co najmniej 2,54 cm. Dodatkowo powierzchnie czołowe rdzeni skalnych wyrównuje się oraz wygładza tak, aby z powierzchnią boczną tworzyły kąt prosty. Kolejno dla cylindrycznych rdzeni określa się pierwotną chropowatość ich powierzchni czołowych (ściany szczeliny) 


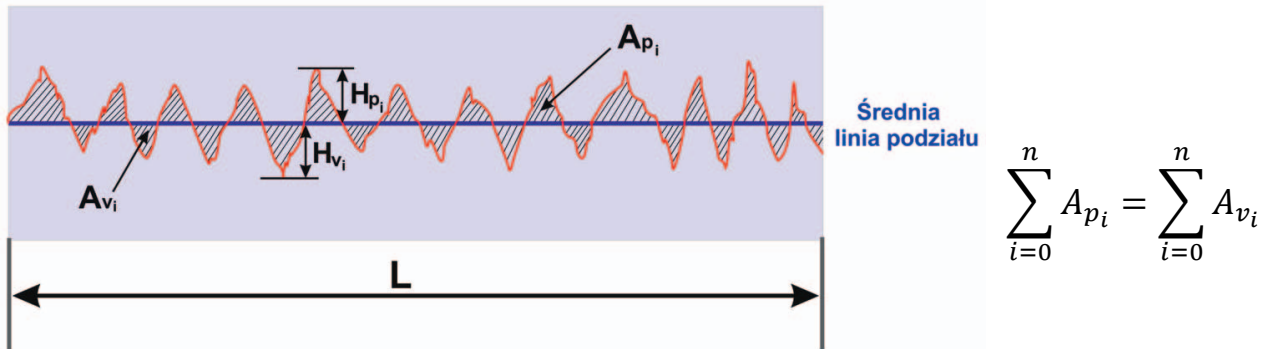

Rys. 2. Przykładowy profil chropowatości powierzchni wzdłuż odcinka pomiarowego dla wytypowanego obszaru na powierzchni ściany szczeliny

Fig. 2. An example of the surface roughness profile along the measurement section for the selected area, on the surface of the fracture face
$A_{f}$ - pole powierzchni ściany szczeliny poddawanej naprężeniu ściskającemu $\left[\mathrm{cm}^{2}\right]$.

Podsadzka poddawana jest działaniu zadanego naprężenia ściskającego i temperatury, przez zadany okres czasu, a następnie powoli redukuje się naprężenie i wyznacza się wielkości charakteryzujące zjawisko embedment. Analizę głębokości i powierzchni wgnieceń określa

(Morales, 2012; Masłowski, 2015; Masłowski i Biały, 2016; Masłowski et al., 2018a, 2018b). Chropowatość wyznacza się za pomocą mikroskopu optycznego umożliwiającego cyfrowe topograficzne obrazowanie oraz analizę chropowatości powierzchni. Metodę wyznaczenia chropowatości powierzchni wzdłuż danego odcinka pomiarowego przedstawiono na rysunku 2

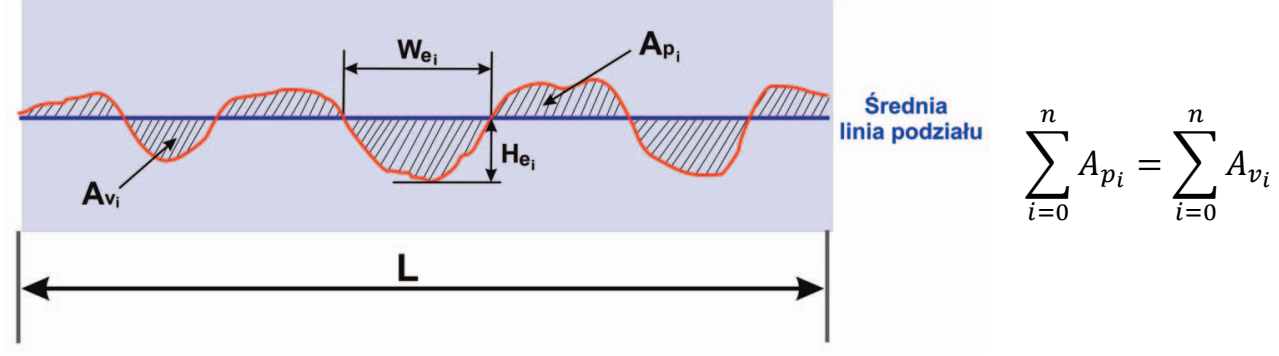

Rys. 3. Przykładowy profil głębokości i szerokości wgnieceń ziaren podsadzki wzdłuż odcinka pomiarowego dla wytypowanego obszaru na powierzchni ściany szczeliny

Fig. 3. Example of profile depth and width of grains embedment along the measurement section for the selected area, on the surface of the fracture face
(Morales, 2012) oraz za pomoca równania (1), (Morales, 2012; Masłowski, 2015; Masłowski i Biały, 2016; Masłowski et al., 2018a, 2018b).

$$
R=\frac{\sum_{i=0}^{n} H_{p_{i}}+\sum_{i=0}^{n} H_{v_{i}}}{n_{p}+n_{v}}
$$

gdzie:

$R$ - chropowatość profilu powierzchni wzdłuż odcinka pomiarowego [mm];

$H_{p . i}$ - wysokość szczytu [mm];

$H_{v, i}$ - głębokość doliny [mm];

$n_{p}-$ liczba wszystkich szczytów [-];

$n_{v}$ - liczba wszystkich dolin [-].

W celu laboratoryjnej symulacji zjawiska embedment, wytworzoną szczelinę pomiędzy dwoma powierzchniami czołowymi cylindrycznych rdzeni skalnych wypełnia się podsadzką w ilości potrzebnej dla uzyskania zadanej koncentracji powierzchniowej, według równania (2), (PN-EN ISO 13503-5, 2009; Morales, 2012; Masłowski, 2015; Masłowski i Biały, 2016; Masłowski et al., 2018a, 2018b).

$$
m_{p}=0,1 \cdot A_{f} \cdot C
$$

gdzie:

$m_{p}$ - masa podsadzki [g];

C - jednostkowe obciążenie wywierane przez podsadzkę (koncentracja powierzchniowa podsadzki) $\left[\mathrm{kg} / \mathrm{m}^{2}\right]$; się przy pomocy mikroskopu optycznego. Wykonuje się cyfrowy topograficzny obraz powierzchni ściany szczeliny w $3 \mathrm{D}$, dla wytypowanego obszaru. Następnie dla tego obszaru wyznacza się średnią głębokość i szerokość wgnieceń oraz średni procentowy rozmiar uszkodzenia powierzchni ściany szczeliny z profili głębokości wzdłuż kilku odcinków pomiarowych (profili głębokości wgnieceń). Metodę wyznaczenia wielkości zjawiska embedment, tj. średniej głębokości i szerokości wgnieceń oraz średniego procentowego uszkodzenia powierzchni ściany szczeliny przedstawiono na rysunku 3, przy zastosowaniu równań (6), (7), (8) (Morales, 2012; Masłowski, 2015, Masłowski i Biały, 2016; Masłowski et al., 2018a, 2018b).

$$
H_{e}=\frac{\sum_{i=0}^{n} H_{e_{i}}}{n_{e}}
$$

gdzie:

$H_{e}$ - średnia głębokość wgnieceń ziaren podsadzki w ścianę szczeliny dla profilu wzdłuż odcinka pomiarowego [mm];

$H_{e . i}$ - głębokość doliny (głębokość wgniecenia ziarna podsadzki w ścianę szczeliny) [mm];

$n_{e}$ - liczba wszystkich dolin (ilość wgnieceń ziaren podsadzki w ścianę szczeliny) [-].

$$
W_{e}=\frac{\sum_{i=0}^{n} W_{e_{i}}}{n_{e}}
$$


gdzie:

$W_{e}$ - średnia szerokość wgnieceń ziaren podsadzki w ścianę szczeliny dla profilu wzdłuż odcinka pomiarowego $[\mathrm{mm}]$;

$W_{e . i}$ - szerokość doliny (szerokość wgniecenia ziarna podsadzki w ścianę szczeliny) [mm].

$$
\operatorname{PUS}_{e}=\frac{\sum_{i=0}^{n} S_{e_{i}}}{L} \cdot 100
$$

gdzie:

$P U S_{e}$ - procentowe uszkodzenie powierzchni ściany szczeliny (wgniecenia ziaren podsadzki na powierzchni ściany szczeliny) dla profilu, tj. wzdłuż odcinka pomiarowego [\%];

$L$ - długość odcinka pomiarowego [mm].

Całkowitą średnią głębokość $H_{c}$ wgnieceń ziaren podsadzki w ściany szczeliny, wyrażoną $\mathrm{w}$ mm, określa się według równania (6). Stanowi ona o wielkości zmniejszenia się pierwotnej rozwartości (szerokości) szczeliny, związanej ze zjawiskiem embedment.

$$
H_{e_{c}}=H_{e . G_{s r}}+H_{e . D_{s r}}
$$

gdzie:

$H_{e . G . s r}$ - średnia głębokość wgnieceń ziaren podsadzki w górną ścianę szczeliny $[\mathrm{mm}]$;

$H_{e . D . s r}$ - średnia głębokość wgnieceń ziaren podsadzki w dolną ścianę szczeliny [mm], będąca średnią arytmetyczną uzyskanych ich wartości z poszczególnych profili dla wytypowanego obszaru.

Całkowitą średnią szerokość $W e_{c}$ wgnieceń ziaren podsadzki w ściany szczeliny, wyrażoną w mm, określa się według równania (7).

$$
W_{e_{c}}=\frac{W_{e . G_{s r}}+W_{e . D_{s r}}}{2}
$$

gdzie:

$W_{e . G . s r}-$ średnia szerokość wgnieceń ziaren podsadzki w górną ścianę szczeliny [mm];

$W_{\text {e.D.sr }}$ - średnia szerokość wgnieceń ziaren podsadzki w dol-

ną ścianę szczeliny [mm], będąca średnią arytmetycz-

ną uzyskanych ich wartości z poszczególnych profili

dla wytypowanego obszaru.

Całkowite średnie procentowe uszkodzenie $P U S_{e . c}$ powierzchni ścian szczeliny (wgniecenia ziaren podsadzki w ścianę szczeliny) określa się według równania (8).

$$
P U S_{e_{c}}=\frac{P U S_{e . G_{s r}}+P U S_{e . D_{S r}}}{2}
$$

gdzie:

$P U S_{\text {e.G.sr }}$ - średnie procentowe uszkodzenie powierzchni górnej ściany szczeliny (wgniecenia ziaren podsadzki na powierzchni ściany szczeliny);

$P U S_{\text {e.D.sr }}$ - średnie procentowe uszkodzenie powierzchni dolnej ściany szczeliny (wgniecenia ziaren podsadzki na powierzchni ściany szczeliny), będące średnią arytmetyczną uzyskanych ich wartości z poszczególnych profili dla wytypowanego obszaru.

\section{Charakterystyka skały złożowej, płynu szczelinującego oraz podsadzki, użytych do badań}

Do badań wykorzystano skałę ilasto-mułowcową (rys. 4a), pochodzącą z polskiego złoża niekonwencjonalnego typu łupkowego shale gas. Charakteryzowała się ona w swoim składzie mineralogicznym znaczną ilością minerałów ilastych 47,7\%. Zawartość kwarcu wyniosła 24,4\%, a węglanów 14,2\%. Ilościowy skład mineralny skał wyliczany był metodą Rietvelda przy pomocy programu komputerowego SIROQUANT, o udokumentowanej przydatności do analizy składu skał zawierających również minerały ilaste. Pomiary ilościowe wykonano w Zakładzie Geofizyki Wiertniczej INiG - PIB na aparacie X'Pert Pro firmy Panalytical wyposażonego w nowoczesny licznik paskowy X-Celerator. Do nasycania skały użyty został płyn szczelinujący na bazie wody wodociągowej, oznaczony jako polimer liniowy (rys. 4b). Posiadał on w swoim składzie: biocyd, środek żelujący (guar, o stężeniu 3,6 g/l), stabilizator minerałów ilastych oraz nanoemulsję. Do podsadzenia zasymulowanej szczeliny została użyta lekka podsadzka ceramiczna 30/50 (rys. 4c) o rozmiarze ziaren rzędu $0,600-0,300 \mathrm{~mm}$ (średnia średnica ziaren podsadzki wynosiła $0,450 \mathrm{~mm}$ ).
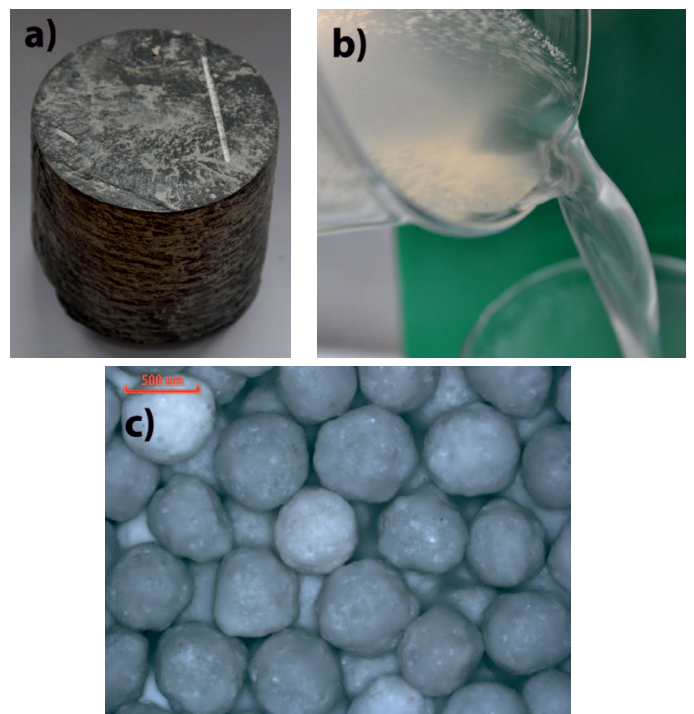

Rys. 4. Materiały użyte do badań: a) skała ilasto-mułowcowa; b) polimer liniowy; c) lekka podsadzka ceramiczna 30/50

Fig. 4. The materials used for testing: a) Shale rock;

b) Fracturing fluid; c) Lightweight ceramic proppant 30/50 


\section{Laboratoryjne zasymulowanie zjawiska embedment oraz analiza otrzymanych wyników}

wakonano na cylindrycznych rdzeniach skalnych o średnicy $2,54 \mathrm{~cm}$. W pierwszej kolejności wyznaczono średnią pierwotną chropowatość powierzchni czołowej rdzenia (ściany szczeliny), według procedury opisanej we wcześniejszej części artykułu. Laboratoryjna symulacja zjawiska wgniatania ziaren podsadzki w ścianę szczeliny polegała na umieszczeniu
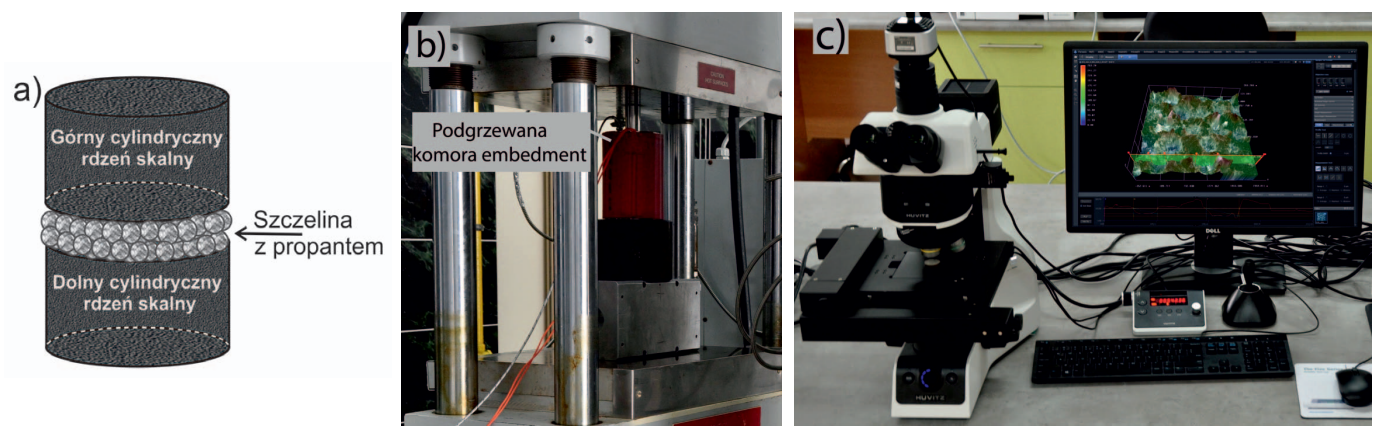

Rys. 5. a) Schemat zasymulowania szczeliny wypełnionej podsadzką; b) Prasa hydrauliczna wraz z podgrzewaną komora do badania zjawiska embedment; c) Mikroskop optyczny HUVITZ HRM-300 3D Profiler wraz z programowaniem 3D Panasis

Fig. 5. a) Schema of simulation of the fracture packed with the proppant; b) Hydraulic press with heating chamber for studying the embedment phenomenon; c) Optical microscope HUVITZ HRM-300 3D Profiler with 3D software Panasis
Wyznaczenie pierwotnej chropowatości powierzchni ścian szczeliny, przedstawiono na rysunkach 6 i 7. podsadzki pomiędzy dwoma powierzchniami czołowymi cylindrycznych rdzeni skalnych (rys. 5a) w komorze do symulacji zjawiska embedment (rys. 5b). Po umieszczeniu komory embedment na prasie hydraulicznej i osiągnięciu zadanej temperatury badania, podsadzkę poddawano oddziaływaniu zadanego naprężenia ściskającego przez zadany okres czasu. Po upływie zadanego okresu redukowano naprężenie ściskające i rozkręcano komorę. Po usunięciu podsadzki, wykonano analizę powierzchni czołowej rdzenia (ściany szczeliny) przy użyciu mikroskopu optycznego (rys. 5c), według procedury opisanej we wcześniejszej części artykułu.
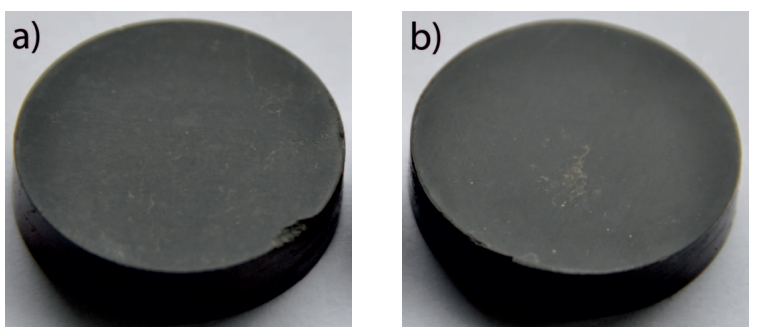

Rys. 6. Powierzchnia czołowa rdzenia przed testem: a) górnego rdzenia i b) dolnego rdzenia

Fig. 6. Surface of the core rock sample, before test: top core face; b) bottom core face
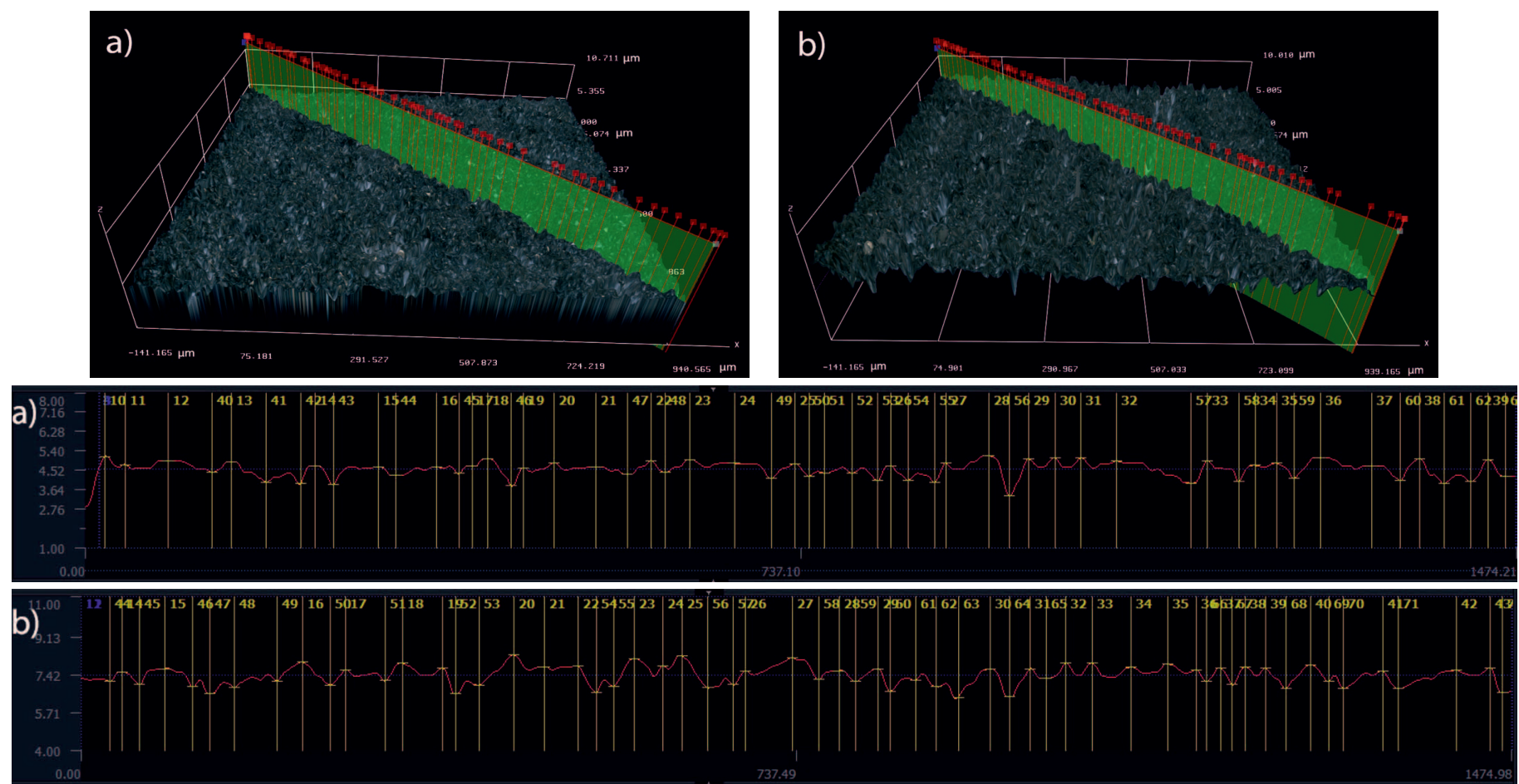

Rys. 7. Określenie pierwotnej chropowatości czołowej rdzeni (obiektyw 50x) dla: a) górnej ściany szczeliny, b) dolnej ściany szczeliny

Fig. 7. Determination of the primary roughness of the core plug (lens 50x), for: a) top fracture face; b) bottom fracture face 
Pierwotna chropowatość powierzchni $R$ dla górnej ściany szczeliny wyniosła $0,00038 \mathrm{~mm}$. Natomiast pierwotna chropowatość powierzchni $R$ dla dolnej ściany szczeliny wyniosła $0,00044 \mathrm{~mm}$.

Warunki wykonania testu zostały przedstawione w tabeli 1. Rdzenie skalne były wstępnie nasycane płynem szczelinującym w temperaturze $70^{\circ} \mathrm{C}$ i ciśnieniu $6,9 \mathrm{MPa}$ przez okres 2 godzin.

Tabela 1. Warunki wykonania testu

Table 1. Test conditions

\begin{tabular}{|l|c|}
\hline Temperatura $\left[{ }^{\circ} \mathrm{C}\right]$ & 70,0 \\
\hline Koncentracja powierzchniowa podsadzki $\left[\mathrm{kg} / \mathrm{m}^{2}\right]$ & 2,44 \\
\hline Naprężenie ściskające $[\mathrm{MPa}]$ & 48,3 \\
\hline Czas działania naprężenia ściskającego, godziny & 6 \\
\hline
\end{tabular}

Uzyskane wielkości zjawiska embedment, zostały przedstawione na rysunkach 8 i 9 oraz w tabeli 2 .
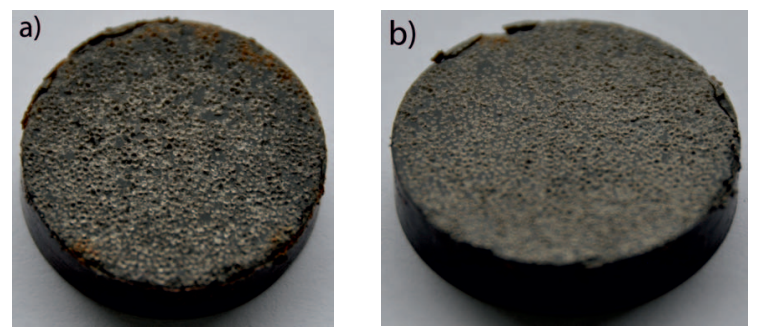

Rys. 8. Wygląd powierzchni czołowej rdzeni po teście: a) górny rdzeń i b) dolny rdzeń

Fig. 8. Surface of the core plug sample, after test: a) top core face, b) bottom core face

Tabela 2. Wyniki analiz wielkości zjawiska embedment dla nasyconej płynem szczelinującym skały ilasto-mułowcowej

Table 2. Results of analyzes of the embedment phenomenon for rock saturated with fracturing fluid

\begin{tabular}{|l|c|c|c|}
\hline \multicolumn{1}{|c|}{ Wielkości zjawiska embedment } & $\begin{array}{c}\text { Górna część } \\
\text { ściany szczeliny }\end{array}$ & $\begin{array}{c}\text { Dolna część } \\
\text { ściany szczeliny }\end{array}$ & Szczelina \\
\hline \hline Całkowita długość odcinków pomiarowych $L_{c}[\mathrm{~mm}]$ & 10,8106 & 10,7707 & 21,5813 \\
\hline Średnia długość jednego odcinka pomiarowego $L[\mathrm{~mm}]$ & 2,7027 & 2,6927 & 2,6977 \\
\hline Średnia głębokość wgnieceń ziaren podsadzki $H e_{s r}[\mathrm{~mm}]$ & 0,0522 & 0,0506 & 0,0514 \\
\hline Średnia szerokość wgnieceń ziaren podsadzki $W e_{s r}[\mathrm{~mm}]$ & 0,3162 & 0,2951 & 0,3056 \\
\hline Średnie procentowe uszkodzenie powierzchni ściany szczeliny $P U S_{e . s r}[\%]$ & 39,9 & 37,4 & 38,7 \\
\hline Całkowita średnia głębokość wgnieceń ziaren podsadzki w ściany szczeliny $H e_{c}[\mathrm{~mm}]$ & $\mathbf{0 , 1 0 2 8}$ \\
\hline Całkowita średnia szerokość wgnieceń ziaren podsadzki w ściany szczeliny $W e_{c}[\mathrm{~mm}]$ & $\mathbf{0 , 3 0 5 6}$ \\
\hline Całkowite średnie procentowe uszkodzenie powierzchni ściany szczeliny $P U S e_{c}[\%]$ & $\mathbf{3 8 , 7}$ \\
\hline
\end{tabular}
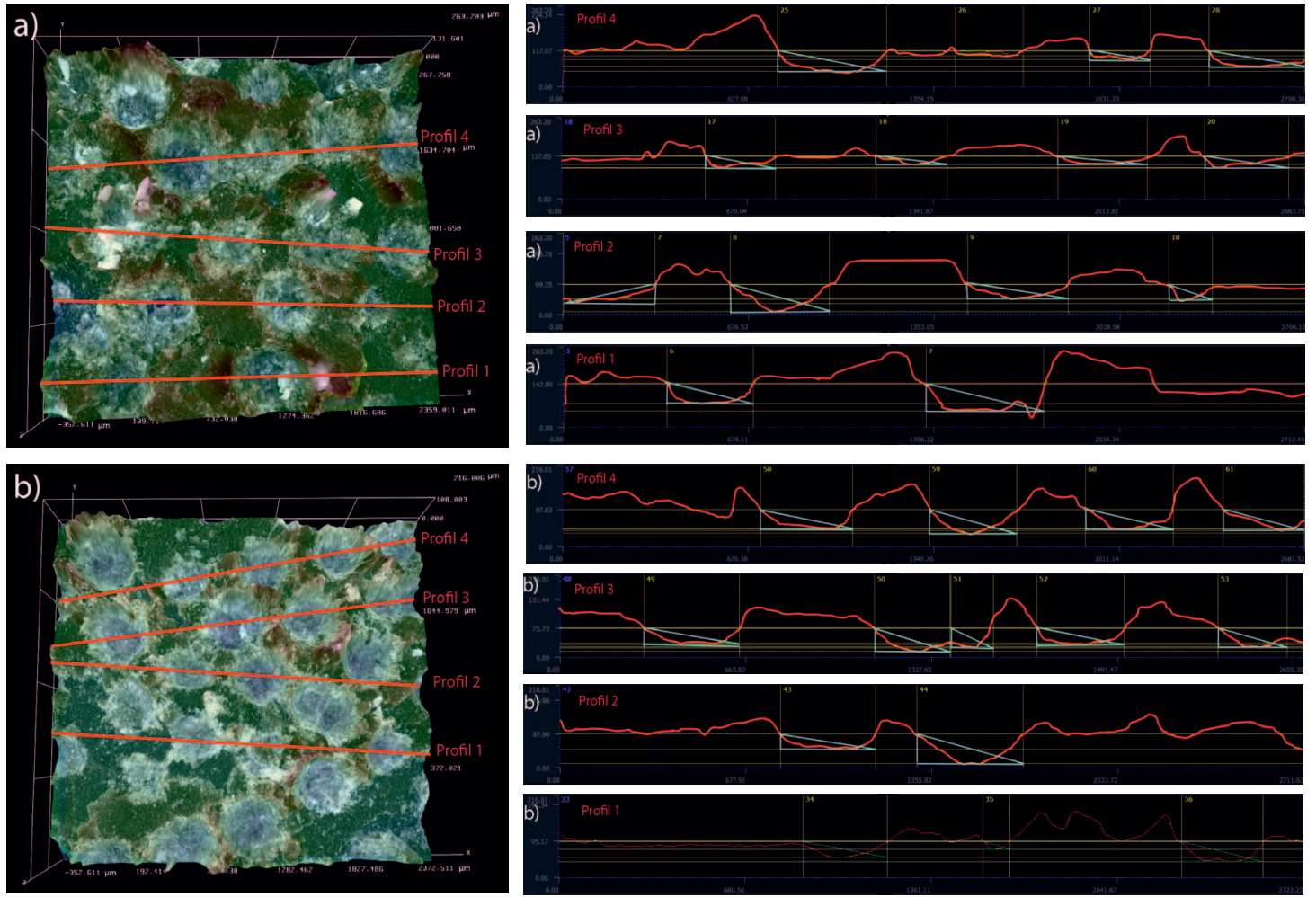

Rys. 9. Określenie wielkości zjawiska embedment (obiektyw 20x): a) górna ściana szczeliny, b) dolna ściana szczeliny

Fig. 9. Determination of the embedment phenomenon (lens 20x): a) top facture face, b) bottom fracture face 


\section{Podsumowanie i wnioski}

Wyniki badań pokazały, że zjawisko wgniatania ziaren podsadzki w ścianę szczeliny (tzw. zjawisko embedment) ma znaczący wpływ na wielkość uszkodzenia powierzchni ściany szczeliny. Badanie wykonano dla wstępnie nasyconej płynem szczelinującym skały złożowej, pochodzącej z polskiego złoża niekonwencjonalnego, charakteryzującego się podwyższoną zawartością minerałów ilasto-mułowcowych. Dla naprężenia ściskającego 48,5 MPa oddziaływującego na lekką podsadzkę ceramiczną o rozmiarze ziaren $0,600-0,300 \mathrm{~mm}$, w temperaturze $70^{\circ} \mathrm{C}$ uzyskano całkowitą średnią głębokość wgnieceń podsadzki w ściany szczeliny, rzędu $0,1028 \mathrm{~mm}$. Całkowita średnia szerokość wgnieceń ziaren podsadzki w ściany szczeliny wyniosła $0,3056 \mathrm{~mm}$. Całkowite procentowe uszkodzenie powierzchni ściany szczeliny przez ziarna podsadzki było rzędu $38,7 \%$. Przedstawiona symulacja oraz obrazowanie zjawiska embedment może stanowić jedną z metod oceny podatności skały na wgniatanie ziaren podsadzki w ściany wytworzonej szczeliny. Powoduje to ograniczenie rozwartości szczeliny oraz wzrost uszkodzenia powierzchni ściany szczeliny po zabiegu hydraulicznego szczelinowania. Tym samym przepływ węglowodorów ze skały do szczeliny oraz do odwiertu jest ograniczony. Wyniki badań zjawiska embedment mogą stanowić wstępną ocenę efektywności podsadzenia szczeliny w zabiegach hydraulicznego szczelinowania na etapie ich projektowania.

Artykuł powstał na podstawie pracy statutowej pt.: Badania wplywu zjawiska embedment na efektywne podsadzenie szczeliny proppantem po zabiegach intensyfikacyjnych - praca INiG - PIB na zlecenie (MNiSW); nr zlecenia: 0056/KS/17, nr archiwalny: DK-4100-56/17.

\section{Literatura}

Moska R., Kasza P., Masłowski M., 2018. Rock anisotropy and brittleness from laboratory ultrasonic measurements in the service of hydraulic fracturing. Acta Geodynamica et Geomaterialia, 1(189): 67-76. DOI: 10.13168/AGG.2018.0005.

Kasza P., 2019. Zabiegi hydraulicznego szczelinowania złóż niekonwencjonalnych i metody ich analizy. Prace Naukowe Instytutu Nafty i Gazu - Państwowego Instytutu Badawczego, 226. DOI: 10.18668/PN2019.226.

Alramahi B., Sundberg M.I., 2012. Proppant Embedment and Conductivity of Hydraulic Fractures in Shales. The $46^{\text {th }}$ US Rock Mechanics/Geomechanics Symposium, Chicago, 24-27.06.2012, ARMA: 12-291.

Czupski M., Kasza P., Wilk K., 2013. Płyny do szczelinowania złóż niekonwencjonalnych. Nafta-Gaz, 1: 42-50.

Gidley J.L., Holditch S.A., Nierode D.A., Veatch R.V., 1989. Recent Advances in Hydraulic Fracturing. Society of Petroleum Engineers, Richardson, TX.
Guo J., Liu Y., 2012. Modeling of Proppant Embedment: Elastic Deformation and Creep Deformation. Society of Petroleum Engineers. DOI: 10.2118/106623-MS.

Kasza P., 2011. Zabiegi stymulacji wydobycia w niekonwencjonalnych złożach węglowodorów. Nafta-Gaz, 10: 697-701.

Legarth B., Huenges E., Zimmermann G., 2005. Hydraulic fracturing in a sedimentary geothermal reservoir: Results and implications. International Journal of Rock Mechanics \& Mining Sciences 42: $1028-1041$

Masłowski M., 2015. Badania zjawiska wciskania ziaren materiału podsadzkowego w ściany szczeliny po zabiegu hydraulicznego szczelinowania złóż niekonwencjonalnych. Nafta-Gaz, 7: 461-471.

Masłowski M., Biały E., 2016. Badania zjawiska embedment w zabiegach stymulacyjnych. Nafta-Gaz, 12: 1101-1106. DOI: 10.18668/ NG.2016.12.13.

Masłowski M., Kasza P., Czupski M., 2018a. Badania podatności skały złożowej typu tight gas na zjawisko embedment ograniczające efektywność zabiegu hydraulicznego szczelinowania. Nafta-Gaz, 10: 822-832. DOI: 10.18668/NG.2016.10.07.

Masłowski M., Kasza P., Czupski M., Wilk K., 2018b. Sposób wyznaczania zmniejszenia rozwartości podsadzonej szczeliny. Urząd Patentowy RP, 10.04.2018. Patent 228609.

Morales H., 2012. Sustaining Fracture Area and Conductivity of Gas Shale Reservoirs for Enhancing Long-Term Production and Recovery. RPSEA Unconventional Gas Conference 2012: Geology, the Environment, Hydraulic Fracturing, Canonsburg, 17-18.04.2012.

Reinicke A., Legarth B., Zimmermann G., Huenges E., Dresenn G., 2006. Hydraulic Fracturing and Formation Damage in a Sedimentary Geothermal Reservoir. ENGINE - Enhanced Geothermal Innovative Network for Europe Workshop 3, Stimulation of reservoir and microseismicity Kartause Ittingen, Zürich, 29.06-1.07.2006, Switzerland.

Reinicke A., Rybacki E., Stanchits S., Huenges E., Dresen G., 2010. Hydraulic fracturing stimulation techniques and formation damage mechanisms - Implications from laboratory testing of tight sandstone - proppant systems. Chemie dee Erde, 70: 107-117. DOI: 10.1016/j.chemer.2010.05.016.

\section{Akty prawne i normatywne}

PN-EN ISO 13503-5 Przemysł naftowy i gazowniczy - Materiały i płyny do dowiercania złóż - Część 5: Procedury pomiaru długotrwałej przewodności materiałów podsadzkowych (ISO 13503-5:2006)

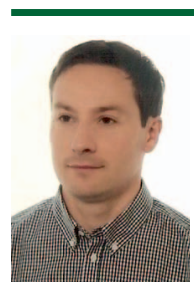

Mgr inż. Mateusz MASŁOWSKI

Asystent w Zakładzie Stymulacji Wydobycia

Węglowodorów

Instytut Nafty i Gazu - Państwowy Instytut Badawczy ul. Lubicz 25 A

31-503 Kraków

E-mail: mateusz.maslowski@inig.pl 